\title{
Rare and unknown canine systemic mastocytosis: clinical and laboratory features of an aberrant c-Kit mutation neoplasia
}

\section{A rara e desconhecida mastocitose sistêmica canina: características clínicas e laboratoriais de uma neoplasia aberrante na mutação c-Kit}

\author{
Carla Sofia Soares ${ }^{1,2, *}$ (D); Leonor Delgado ${ }^{3,4, *}$; Sónia Morgado ${ }^{1}$; Pedro Pires Carvalho ${ }^{5,6,7} ;$ Luís Carlos Barros ${ }^{1,5}$ \\ ${ }^{1}$ VetLamaçães Small Animal Clinic, Braga, Portugal \\ ${ }^{2}$ University of Trás-os-Montes and Alto Douro, Animal and Veterinary Research Centre, Vila Real, Portugal \\ ${ }^{3}$ INNO Veterinary Laboratory, Braga, Portugal \\ ${ }^{4}$ Instituto de Investigação e Formação Avançada em Ciências e Tecnologias da Saúde, Instituto Universitário de Ciências da Saúde, \\ Gandra, Portugal \\ ${ }^{5}$ University School Vasco da Gama, Coimbra, Portugal \\ ${ }^{6}$ University School Vasco da Gama, Vasco da Gama Research Center, Coimbra, Portugal \\ ${ }^{7}$ Vetherapy - Research and Development in Biotechnology, Coimbra, Portugal \\ *Both authors contributed equally to this manuscript.
}

\begin{abstract}
Systemic mastocytosis (SM) pathology is extremely rare in canine practice, with insufficient reported data. The knowledge of the clinical behavior of this pathology is scarce. In human medicine, SM has been widely investigated, being defined as a rare hematopoietic disorder by the World Health Organization (2016), within the type of myeloproliferative neoplasms. Herein, we describe a systemic mastocytosis case in a Portuguese Serra-da-Estrela dog, where a cutaneous grade III/high-grade MCT was also diagnosed. The clinical decline of the animal and owner's insistence throughout anamnesis that the dog was markedly different after the cytologic exam performed in another clinic, along with both severe eosinophilia and hepatomegaly, led to the clinical suspicion of SM. The animal passed away 7 days later. Post-mortem investigation confirmed SM pathology, and a deletion of 15 base pairs change on c-Kit gene exon 11 was identified. Contemplating the low number of cases described in the literature, this publication aims to disclose clinical and laboratory features of rare and poorly described canine SM, taking into consideration human outcomes described in the literature.
\end{abstract} Keywords: Eosinophilia. Hepatomegaly. C-Kit mutation. Systemic mastocytosis.

\section{RESUMO}

A patologia da mastocitose sistêmica (SM) é extremamente rara na prática clínica canina, com escassos casos descritos na literatura científica. O conhecimento do comportamento clínico desta patologia é mínimo. Na medicina humana, a SM tem sido amplamente investigada, sendo definida como uma doença hematopoiética rara pela Organização Mundial da Saúde (2016), dentro do tipo de neoplasias mieloproliferativas. Descrevemos aqui um caso de mastocitose sistêmica num cão Serra-da-Estrela português, diagnosticado também com um mastocitoma cutâneo grau III / alto grau. O declínio clínico do animal e a insistência do proprietário durante a anamnese de que o cão estava marcadamente diferente após o exame citológico realizado em outra clínica, juntamente com eosinofilia e hepatomegalia graves, levantaram a suspeita clínica de SM. O animal faleceu 7 dias depois. A investigação post-mortem confirmou a patologia SM, e o estudo molecular revelou uma deleção de 15 pares de bases no exon 11 do gene c-Kit. Contemplando o baixo número de casos descritos na literatura, o objetivo desta publicação é divulgar características clínicas e laboratoriais de SM canina, levando em consideração informações clínicas descritas em humanos.

Palavras-chave: Eosinofilia. Hepatomegalia. Mutação c-Kit. Mastocitose sistêmica. 
Correspondence to:

Carla Sofia Soares

VetLamaçães Small Animal Clinic

Av. D. João II,139

4715-303 Braga, Portugal

e-mail: carlasoares.medvet@gmail.com

Received: October 6, 2020

Approved: January 21, 2021

How to cite: Soares CS, Delgado L, Morgado S, Carvalho PP, Barros LC. Rare and unknown canine systemic mastocytosis: clinical and laboratory features of an aberrant c-Kit mutation neoplasia. Braz J Vet Res Anim Sci. 2021;58:e175896. https://doi.org/10.11606/issn.16784456.bjvras.2021.175896

\section{Introduction}

Mast cell tumors (MCTs), also recognized as mastocytomas, are common in canine practice, representing up to $16-21 \%$ of canine skin tumors (Blackwood et al., 2012). Mast cells (MCs) derive from hematopoietic lineage cells in the bone marrow, circulating in the blood and migrate into peripheral tissues, where they differentiate into mature MCs under the influence of various tissue-specific elements (Moon et al., 2014). MCs, also described as mastocytes, constitute an important host defense resident cellular population, frequent in the mucosal surfaces, often near epithelial cells, glands, smooth muscle cells, and nerves, and are widely distributed throughout the systemic bloodstream (Moon et al., 2014).

Mastocytosis involves the systemic proliferation of MCs, affecting the bone marrow, spleen, liver lymph nodes, gastrointestinal organs, and even skin in humans, dogs, and cats (Pariser \& Gram, 2015).

In humans, mastocytosis has been widely investigated and is defined as a rare hematopoietic disorder. The World Health Organization (WHO) categorized mastocytosis within the type of myeloproliferative neoplasms (Wagner \& Staubach, 2018). In humans, and rendering to the 2016 WHO statement, mastocytosis is categorized in subvariants of cutaneous mastocytosis (with no systemic involvement), systemic variants (SM), and localized MCs tumors (Valent et al., 2017a). According to human data, the prognosis in cutaneous mastocytosis is defined as good, but the prognosis in $\mathrm{SM}$ is variable, alternating from indolent forms with normal life expectancy, to precipitously declining progressions (MetCalfe 2008; Valent et al., 2017b).

Nevertheless, SM is an extremely rare pathology in canine practice, with insufficient knowledge of the clinical behavior of this pathology. The lack of specific clinical manifestations in SM is pointed to as a sponsor for diagnostic adjournment.

This publication aims to disclose clinical and laboratory features of rare and poorly described canine SM, taking into consideration human outcomes.

\section{Case Report}

An 11-year old Portuguese canine breed Serra-da-Estrela male dog, having mostly an indoor habitat regime, was presented for consultation (day 1), referenced from another veterinary clinic (considered the day 0 ). The dog weighed $46 \mathrm{~kg}$ and presented a 4/9 body condition score (Freeman et al., 2011). According to the owner, the dog presented an enlarged abdomen within the last $24 \mathrm{~h}$ and was reticent to gait. The owner also mentioned that a cutaneous mass was subjected to a fine needle aspiration cytology, four days before, in the first assisting clinic. The owner insisted that, since this event, the animal has been apathetic, with evidently reduced food intake, and gasping. When interrogated, the owner confirmed the existence of pasty stools and an aqueous regurgitation immediately after water intake, three days and $4 \mathrm{~h}$ beforehand, respectively.

At the consultation, the dog presented a dilated abdomen, a respiratory rate of 47 breaths/minute, a cardiac frequency of 132 beats/minute, intense pink colored mucous membranes with a refiling time of $2.5 \mathrm{sec}$. The canine was hydrated, presenting $38.7^{\circ} \mathrm{C}$ rectal temperature. The dog was conscious, reactive to stimuli, but lethargic. No abnormal sounds were detected in the cardio-pulmonary auscultation exam. Fluid therapy was performed with intravenous Ringer lactate solution, at a rate of $145 \mathrm{~mL}$ / hour, through a peripheric cephalic venous catheter. Oxygen was given through a nasal cannula. The canine presented a moderate hypertensive state (Acierno et al., 2018).

From the historical record of the patient, there were sudden episodes of syncope, five years earlier, associated with hypoglycaemic states, presumably related to long fasting periods due to behavioral issues. Two years before, the animal was diagnosed with degenerative joint disease, at the level of its left shoulder and both hip joints, conducting at that time, intra-articular treatment with autologous bone-marrow aspiration concentrate combined with platelet concentrate. Over the past six months, the dog was receiving daily a commercialized veterinary complement of hemp oil, regularly, with intermittent intervals for six consecutive days of firocoxib as an integrated protocol for pain rescue (approximately one episode within two months period, according to the owner). The patient had an updated vaccine and both internal and external deworming protocols, 
including heartworm and leishmaniosis prevention. The results of a complete medical check-up performed 10-months earlier were unremarkable.

Hematological analysis revealed neutrophilia, prominent eosinophilia, mild azotemia, hypoproteinaemia, and increased prothrombin time (PT) (Table 1). Pericardial and cardiac morphologic abnormalities were ruled out by cardiac ultrasound. Abdominal ultrasound disclosed severe hepatomegaly, with the caudate hepatic lobe reaching the right caudal quadrant of the abdomen, passing the cranial limits of the urinary bladder, enlargement of the spleen, and local lymph nodes, and an abdominal 4 points fluid score. Both liver and spleen disclosed a diffuse homogeneous hypoechoic parenchymal pattern.

Table 1 - Hematology, serum and urinary assessment panel of the dog.

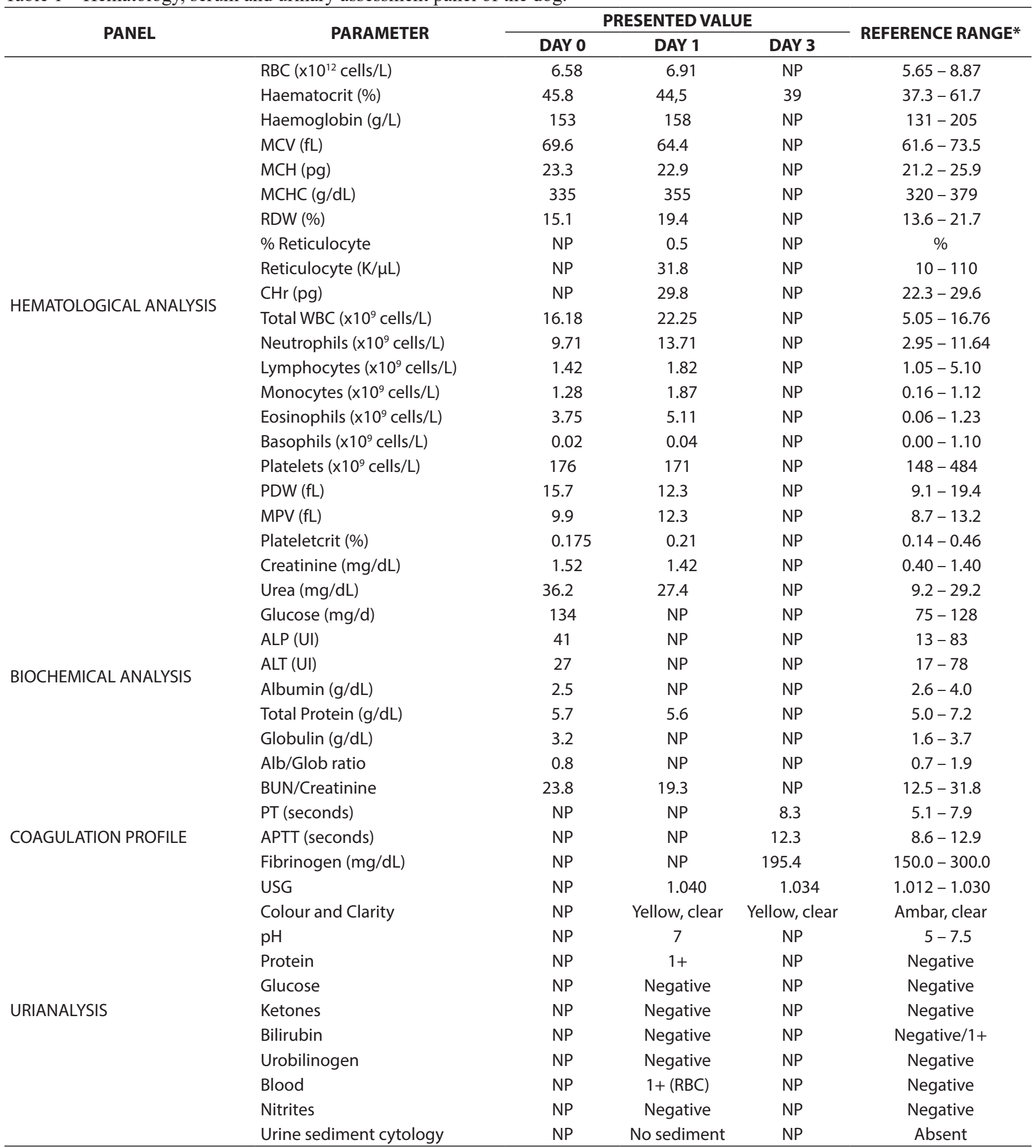

Abbreviations: APTT, activated partial thromboplastin time; NP, not performed; PT, prothrombin time; RBC, red blood cells; USG, urine specific gravity; WBC, white blood cells. *) Hematological analysis performed by ProCyte DX Haematology Analyzer (IDEXX, USA); Coagulation profile performed by coagulometer Sysmex CA-450; Biochemical analyses performed using DRI-CHEM 4000i (FUJIFILM, USA). The reference ranges were recommended by the respective manufacturers and previously clinical and scientifically validated. 
Abdominocentesis drained $370 \mathrm{~mL}$ of a yellow-reddish fluid, classified as a sterile eosinophilic effusion (Figure 1A). Considerable MCs were observed on the blood smear preparation of the buffy coat (Figure 1B).
Considering the hypothesis of an MCTs degranulation event, the therapeutic plan was implemented, consisting of diphenhydramine hydrochloride $1 \mathrm{mg} / \mathrm{kg}$ IM q12 $\mathrm{h}$, ranitidine $2 \mathrm{mg} / \mathrm{kg} \mathrm{SC}$ q12 h, prednisolone $1.5 \mathrm{mg} / \mathrm{kg}$ PO q12 h, omeprazole

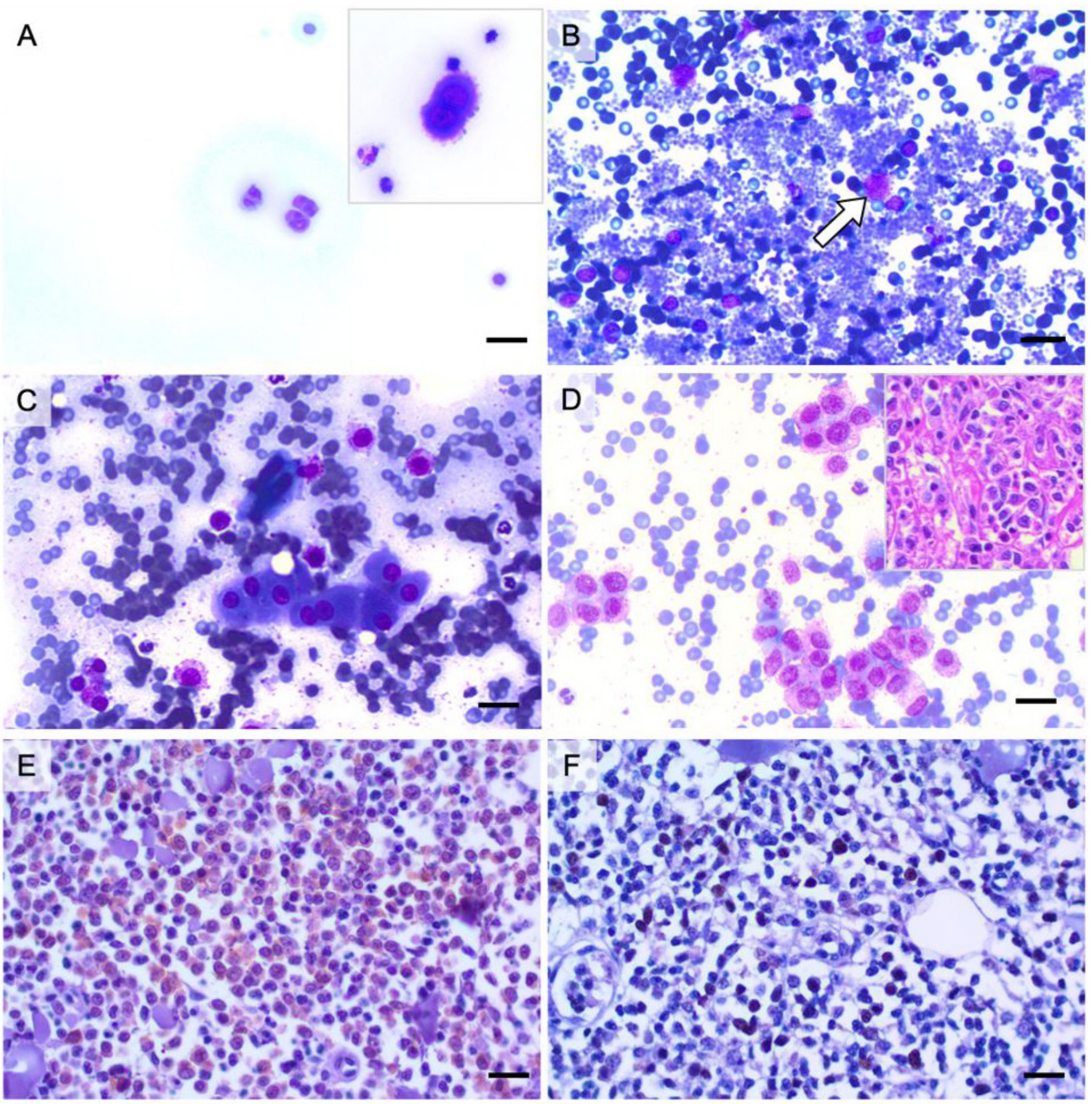

Figure 1 - Microphotographs of cavitary fluid, buffy coat smear, cutaneous mass, and liver cytologic examinations of the dog. (A) Sterile eosinophilic abdominal effusion with moderate cellularity, red blood cells, non-degenerate neutrophils, eosinophils (>20\%), and occasional mesothelial cells (inset); lymphocytes and macrophages were visualized and no evident MCs were detected on the microscopic examination; (B) Buffy coat smear of the patient, demonstrating mastocyte presence (arrow); (C) Liver fine needle cytology, revealing poorly granulated mastocytes disposed of with the resident hepatic cells; eosinophils were also identified; (D) Cutaneous mass non-aspirate cytology, characterized by a cluster of mastocytes with poorly granular cytoplasm and prominent nucleoli, suggesting a poorly differentiated cutaneous mast cell tumor, confirmed by histological analysis, showing an extensive and infiltrative proliferation of atypical mast cells, with scarce intracytoplasmic granulation, marked anisokaryosis and pleomorphism, intermingled with few eosinophils (inset); (E) Cytoplasmatic KIT immunohistochemical staining, pattern III of cutaneous MCT; (F) Nuclear immunohistochemical staining in neoplastic cells of cutaneous MCT. A-D, Romanowsky stain; bar $=20 \mu \mathrm{m}$. E, IHQ, Ki-67; bar $=20 \mu \mathrm{m}$. F, $\mathrm{IHQ}, \mathrm{CD} 117$; bar $=20 \mu \mathrm{m}$. 
$1 \mathrm{mg} / \mathrm{kg}$ PO q24 h and benazepril $0.5 \mathrm{mg} / \mathrm{kg}$ PO q24 h PO. Tramadol $4 \mathrm{mg} / \mathrm{Kg}$ q $12 \mathrm{~h} \mathrm{SC}$ was administered for two days due to abdominal discomfort on palpation exam. Amoxicillin with clavulanic acid (20 mg/kg SC q12 h) was administrated due to neutrophilia and monocytosis.

Four hours later the patient was without oxygen therapy support. Food intake was performed voluntarily after $5 \mathrm{~h}$ of hospitalization.

Non-aspirate fine needle cytology of the cutaneous mass was performed, for the validation of the first cytology performed in the first attending clinic, after a gentle cleansing of the skin. The $2 \times 3 \mathrm{~cm}$ mass was minimally manipulated, revealing no mobility at the palpation, with a firm and hard consistence, irregular shape, localized in the dorsal lumbar-sacral cutaneous region.

Microscopic analysis of the mass revealed abundant cellular content, constituted by mastocytes, with poorly granulated cytoplasm. Multinucleation and anisokaryosis were observed. Nuclear pleomorphism was present, characterized by nonrounded nuclear forms. Eosinophils were identified, disposed of within the cellular population (score 3+). Cytologic evaluation of the cutaneous mass (Figure 1C) was compatible with a high-grade mast cell tumor (Camus et al., 2016).

Considering the clinical stabilization of the patient and targeting the lesion excision for its classification and selection of probable chemotherapeutic plan, the dog was submitted to general anesthesia. The excision of the cutaneous mass and guided-ultrasound non-aspirate liver cytology were performed (Figure 1D). The surgery was without complications. Five hours after the surgery, the animal was lethargic, and oxygen therapy was provided. The animal became stuporous and died within $24 \mathrm{~h}$ after the surgery.

A cosmetic necropsy was performed following the owner's approval. The post-mortem examination revealed the presence of multiple poor-delimitated nodules disseminated on the liver, spleen, and lymph nodes, and hemorrhagic effusion. The liver aspirate cytology revealed profuse poorly granulated mastocytes disposed of with the resident hepatic cells and eosinophils were also identified. Post-mortem histopathological examination confirmed visceral mastocytosis diagnosis, revealing an extensive and infiltrative proliferation of atypical mast cells, with scarce intracytoplasmatic granulation, marked anisokaryosis and pleomorphism, with a high mitotic count ( $>6 / 10 \mathrm{HPF}$ ) compatible with a high-grade mast cell tumor (Kiupel et al., 2011).

Immunohistochemical analysis revealed a diffuse cytoplasmatic KIT staining - pattern III. Ki-67 immunohistochemical analysis revealed an average positive cell per gird area above 23 which is considered a high index (Figure 2). An identical neoplastic population was found disseminated on the liver, spleen, and lymph nodes, confirming a diagnosis of visceral mastocytosis (Figure 2).

Possible mutations on multiple exons of the c-Kit gene were analyzed by PCR technique, namely on exons $8,9,11,14$ e 17. A deletion of 15 base pairs (bp) on the c-Kit gene exon 11 was identified. On remaining exons, the results were as follows: on exon 17 absence of punctual mutation A813P and D815H; on exon 8 absence of punctual mutation Q430R, internal tandem duplications (ITD), insertions or deletions; on exon 9 absence of punctual mutations S479I, N508I and A510V, and on exon 14 absence of punctual mutation T669I.

\section{Discussion}

$\mathrm{SM}$, also designed as visceral mastocytosis, is a rare, highly lethal, and poorly reported disorder in canine practice. The marked eosinophilia and increase of circulating MCs in the bloodstream were the diagnostic clues that reinforced the clinical suspicion of the SM in this case. Moreover, gastrointestinal signs were subtle. Recurrent syncope episodes are reported in human SM, explained by the
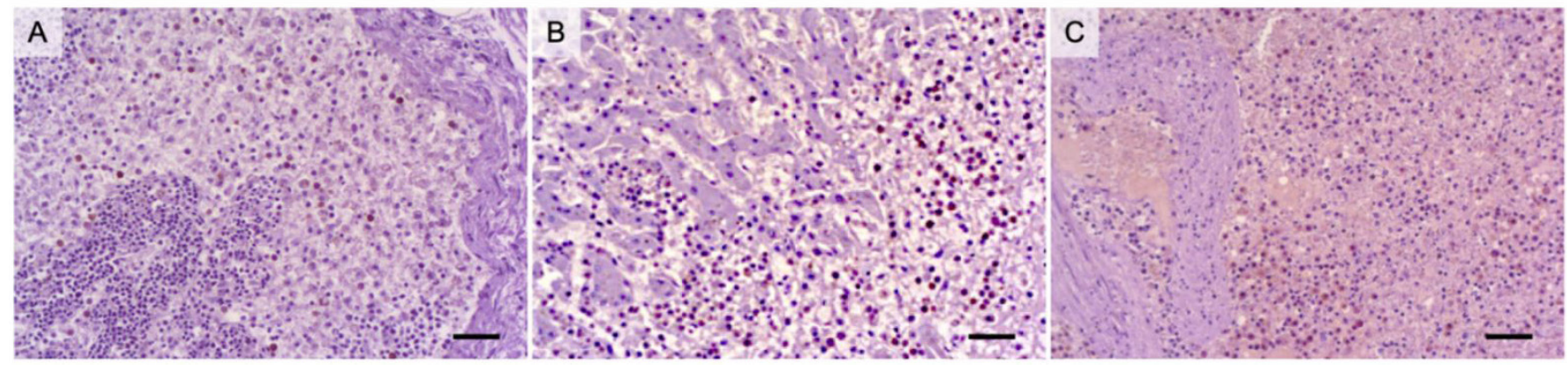

Figure 2 - Microphotographs from immunohistochemical staining from abdominal organs of the dog. (A) KIT immunohistochemical staining (pattern III) on disseminated neoplastic MCs on lymph node (IHQ, CD117; bar = $50 \mu \mathrm{m})$; (B) KIT immunohistochemical staining (pattern III) on disseminated neoplastic MCs on the liver (IHQ, CD117; bar = 50 $\mu$ m); (C) KIT immunohistochemical staining (pattern III) on disseminated neoplastic MCs on spleen (IHQ, CD117; bar $=50 \mu \mathrm{m})$. 
vasodilatation sponsored by MCs mediators (Akin, 2017). Our canine also presented a history of syncope episodes, during a limited period.

Based on human findings, the association between cutaneous forms of mastocytoma and SM is currently accepted, and some studies have suggested that cutaneous MCTs may be a predictive factor for SM (O'Keefe et al., 1987). Nevertheless, the absence of cutaneous MCTs in veterinary patients with SM is possible, also designated as primary visceral mastocytosis, being more common in cats (Takahashi et al., 2000). A clinical study involving 10 canine visceral mastocytosis cases without skin involvement, identified MCTs masses localized at the intestinal region in 6 cases, being impossible to localize the tumor in three dogs (Takahashi et al., 2000). Additionally, the same work suggested a predisposition of male dogs for SM and a considerable post-surgery mortality rate (Takahashi et al., 2000). Paraneoplastic signs are frequently described in aggressive forms of MCTs, being associated with the degranulation of the tumor, causing the release of biologically active substances, that promotes a rapid influx of calcium ions into the cells (Blackwood et al., 2012; Misdorp, 2004). The authors believe that the advanced stage of the disease (SM) determined the clinical decline of the patient, with no contribution of the cytological exam performed in the first assisting clinic. Clinical signs related to degranulation occurrence are more frequently related to visceral or disseminated MCTs (Blackwood et al., 2012).

Some studies showed that MCTs with mutations in exon 11 tend to be more aggressive tumors (Tamlin et al., 2019). Studies on canine cutaneous MCTs were reported in the same exon deletions in a few base-pairs (bp), but deletions in $21 \mathrm{bp}$ were reported in one research (Tamlin et al., 2019). Proto-oncogene c-Kit mutational status is conserved between any primary and its matched secondary tumor, suggesting that both can be used for c-Kit mutational testing (Marconato et al., 2014).

The similarities between human and canine lethal SM are surprising. Mutations in the c-Kit region are frequently identified in neoplastic MCs of dogs, humans, and even cats, contributing to mast cell carcinogenesis (Tamlin et al., 2019). The advance on human SM may benefit veterinary patients through the application of translational approaches, with the administration of specific chemotherapy agents that have recognized benefits in the disease, namely tyrosine kinase inhibitors, based on the mutation of the c-Kit region expressed by neoplastic cells (Nakano et al., 2017). Conversely, recent molecular findings reveal that most human SM cases express the D816V-mutated variant of KIT, conferring resistance against several tyrosine kinase inhibitors (TKI), such as imatinib. Even so, c-Kit screening is always recommended in veterinary settings. Human cases of aggressive SM conversion into myeloproliferative neoplasm have been treated with combined advanced therapies such as allogeneic hematopoietic stem cell transplantation, poorly explored in veterinary medicine (Wagner \& Staubach, 2018).

\section{Conclusion}

To our knowledge, this is the first report of systemic mastocytosis in a Portuguese canine breed, being one of the few describing both clinical and laboratory features associated with this pathology.

The execution of complementary exams for mastocytosis confirmation such as the liver, spleen, and accessible regional drainage lymph nodes sampling for cytologic evaluation is recommended to assume the clinical decisions, and for a diagnostic procedure, especially in cases where an increase of circulating MCs in the bloodstream and both severe eosinophilia and hepatosplenomegaly are detected. Medical treatment based on prednisolone, diphenhydramine, and $\mathrm{H} 1 / \mathrm{H} 2$ antagonist, and even chemotherapy once the disease is detectable is encouraged. Moreover, even with a poor prognosis, an early implementation of a chemotherapeutic plan should be pondered, considering the unavoidable time delay inherent to the obtainment of conclusive laboratory results.

\section{Conflict of interests}

The authors declared no potential conflicts of interest concerning the research, authorship, and/or publication of this article.

\section{Ethics statement}

The owners of the canine patient provided written informed consent for both diagnostic assessment and publication of this case report, with accompanying images.

\section{Acknowledgements}

The authors are grateful to VetLamaçães members, Susana Costa and nurse Verónica Salgado for their contribution to this publication. The main authors also acknowledged Pipos' owners for their altruistic attitude, manifested by their interest in the publication of this case. 


\section{References}

Acierno MJ, Brown S, Coleman AE, Jepson RE, Papich M, Stepien RL, Syme HM. ACVIM consensus statement: guidelines for the identification, evaluation, and management of systemic hypertension in dogs and cats. J Vet Intern Med. 2018;32(6):1803-22. http://dx.doi.org/10.1111/jvim.15331. PMid:30353952.

Akin C. Mast cell activation syndromes. J Allergy Clin Immunol. 2017;140(2):349-55. http://dx.doi.org/10.1016/j. jaci.2017.06.007. PMid:28780942.

Blackwood L, Murphy S, Buracco P, De Vos JP, De FornelThibaud P, Hirschberger J, Kessler M, Pastor J, Ponce F, Savary-Bataille K, Argyle DJ. European consensus document on mast cell tumours in dogs and cats. Vet Comp Oncol. 2012;10(3):1-29. http://dx.doi.org/10.1111/j.14765829.2012.00341.x. PMid:22882486.

Camus MS, Priest HL, Koehler JW, Driskell EA, Rakich PM, Ilha MR, Krimer PM. Cytologic criteria for mast cell tumor grading in dogs with evaluation of clinical outcome. Vet Pathol. 2016;53(6):1117-23. http://dx.doi. org/10.1177/0300985816638721. PMid:27034386.

Freeman L, Becvarova I, Cave N, MacKay C, Nguyen P, Rama B, Takashima G, Tiffin R, van Beukelen P, Yathiraj S. WSAVA Nutritional Assessment Guidelines. J Feline Med Surg. 2011;13(7):516-25. http://dx.doi.org/10.1016/j. jfms.2011.05.009. PMid:21704901.

Kiupel M, Webster JD, Bailey KL, Best S, DeLay J, Detrisac CJ, Fitzgerald SD, Gamble D, Ginn PE, Goldschmidt MH, Hendrick MJ, Howerth EW, Janovitz EB, Langohr I, Lenz SD, Lipscomb TP, Miller MA, Misdorp W, Moroff S, Mullaney TP, Neyens I, O’Toole D, Ramos-Vara J, Scase TJ, Schulman FY, Sledge D, Smedley RC, Smith K, W. Snyder P, Southorn E, Stedman NL, Steficek BA, Stromberg PC, Valli VE, Weisbrode SE, Yager J, Heller J, Miller R. Proposal of a 2-tier histologic grading system for canine cutaneous mast cell tumors to more accurately predict biological behavior. Vet Pathol. 2011;48(1):147-55. http://dx.doi. org/10.1177/0300985810386469. PMid:21062911.

Marconato L, Zorzan E, Giantin M, Di Palma S, Cancedda $S$, Dacasto M. Concordance of c-kit mutational status in matched primary and metastatic cutaneous canine mast cell tumors at baseline. J Vet Intern Med. 2014;28(2):54753. http://dx.doi.org/10.1111/jvim.12266. PMid:24372836.

MetCalfe DD. Mast cells and mastocytosis. Blood. 2008;112(4):946-56. http://dx.doi.org/10.1182/ blood-2007-11-078097. PMid:18684881.

Misdorp W. Mast cells and canine mast cell tumours. A review. Vet Q. 2004;26(4):156-69. http://dx.doi.org/10.10 80/01652176.2004.9695178. PMid:15663212.
Moon TC, Befus AD, Kulka M. Mast cell mediators: their differential release and the secretory pathways involved. Front Immunol. 2014;5:569. http://dx.doi.org/10.3389/ fimmu.2014.00569. PMid:25452755.

Nakano Y, Kobayashi M, Bonkobara M, Takanosu M. Identification of a secondary mutation in the KIT kinase domain correlated with imatinib-resistance in a canine mast cell tumor. Vet Immunol Immunopathol. 2017;188:84-8. http:// dx.doi.org/10.1016/j.vetimm.2017.05.004. PMid:28615132.

O'Keefe DA, Couto CG, Burke-Schwartz C, Jacobs RM. Systemic mastocytosis in 16 dogs. J Vet Intern Med. 1987;1(2):75-80. http://dx.doi.org/10.1111/j.1939-1676.1987. tb01990.x. PMid:3506091.

Pariser MS, Gram DW. Urticaria pigmentosa-like disease in a dog. Can Vet J. 2015;56(3):245-8. PMid:25750443.

Takahashi T, Kadosawa T, Nagase M, Matsunaga S, Mochizuki M, Nishimura R, Sasaki N. Visceral mast cell tumors in dogs: 10 cases (1982-1997). J Am Vet Med Assoc. 2000;216(2):222-6. http://dx.doi.org/10.2460/ javma.2000.216.222. PMid:10649758.

Tamlin VS, Dobson EC, Woolford L, Peaston AE. DNA purification increases PCR-amplifiable DNA extracted from formalin-fixed, paraffin-embedded canine mast cell tumors for routine KIT mutation detection. J Vet Diagn Invest. 2019;31(5):756-60. http://dx.doi.org/10.1177/1040638719867743. PMid:31378162.

Valent P, Akin C, Metcalfe DD. Mastocytosis: 2016 updated WHO classification and novel emerging treatment concepts. Blood. 2017a;129(11):1420-7. http://dx.doi.org/10.1182/ blood-2016-09-731893. PMid:28031180.

Valent P, Akin C, Hartmann K, Nilsson G, Reiter A, Hermine O, Sotlar K, Sperr WR, Escribano L, George TI, KluinNelemans HC, Ustun C, Triggiani M, Brockow K, Gotlib J, Orfao A, Schwartz LB, Broesby-Olsen S, Bindslev-Jensen C, Kovanen PT, Galli SJ, Austen KF, Arber DA, Horny H-P, Arock M, Metcalfe DD. Advances in the classification and treatment of mastocytosis: current status and outlook toward the future. Cancer Res. 2017b;77(6):1261-70. http://dx.doi. org/10.1158/0008-5472.CAN-16-2234. PMid:28254862.

Wagner N, Staubach P. Mastocytosis - pathogenesis, clinical manifestation and treatment. J Dtsch Dermatol Ges. 2018;16(1):42-57. PMid:29314691.

Financial Support: None. 